\title{
Renal haemodynamics and organ damage in young hypertensive patients with different plasma renin activities after ACE inhibition
}

\author{
C. M. Erley, M. Holzer, B. K. Krämer and T. Risler \\ University of Tuebingen, Section of Nephrology and Hypertensıon, Tuebingen, Germany
}

\begin{abstract}
We describe our observations concerning differences in two groups of young hypertensive patients according to their renin activities after ACE inhibition. Seventeen of these patients (age $26 \pm 7$ years), so far untreated, were investigated prospectively for hormone levels (renin, aldosterone, vasopressin), microalbuminuria, renal haemodynamics (inulin and PAH clearance) and signs of organ damage (echocardiography, fundoscopy). Secondary forms of hypertension were excluded by routine methods, including angiography. We differentiated two groups of young hypertensive patients. Group $1(n=9)$ had a false positive captopril test with elevated renin activities after ACE inhibition with captopril $(8.4 \pm 5$ $\mathrm{ng} / \mathrm{ml}$ per hour) compared to group 2 (renin activity: $2.2 \pm 1.3 \mathrm{ng} / \mathrm{ml}$ per hour) or an increase of $>400 \%$ of renin activity after ACE inhibition. Baseline renin activities and sodium excretion did not differ between the groups. Group 1 also showed significantly greater GFR, FF, and microalbuminuria, as well as signs of organ damage, with left ventricular hypertrophy and hypertensive changes in fundoscopy. There were no differences between the groups concerning mean arterial blood pressure and duration of hypertension. In conclusion, we were able to demonstrate that patients with highly stimulated renin activities showed signs of visceral organ damage and renal hyperfiltration compared to the normal renin activity group after ACE inhibition. Investigations of the reninangiotensin-aldosterone system with $\mathrm{ACE}$ inhibitors
\end{abstract}

Correspondence and offprint requests io Christiane M Erley. MD. University of Tuebingen, Medical Sectıon HI. Otfried-Müller-Str 10. 7400 Tuebingen. Germany. might constitute a helpful indicator of renal changes and organ damages in young hypertensive patients.

Key words: ACE inhibition; glomerular hyperfiltration; hypertension; left ventricular hypertrophy; microalbuminuria; renin

\section{Introduction}

Recently we reported the failure of the captopril test to detect renal artery stenosis in young hypertensive patients [1]. Nearly $40 \%$ of our young hypertensive outpatients showed a marked increase of plasma renin activities after ACE inhibition without showing evidence of renal artery stenoses, as excluded by angiography. Baseline renin activities did not differ between the groups and pronounced responses to captopril stimulation could not be explained by different sodium excretion rates. This cohort of young hypertensive patients with a false positive captopril test showed microproteinuria significantly more often compared to a control group.

As it is of great potential importance to evaluate the association of renin concentrations, renal haemodynamics, microalbuminuria, and vascular damage in patients with essential hypertension we started a prospective study in young hypertensive patients. This article will report on our observations in 17 young hypertensive patients matched for blood pressure as well as age and separated according to their response to ACE inhibition. 


\section{Subjects and methods}

From April 1990 to November 1990 ue prospectively investigated 17 young outpatients with hypertension according to their response to ACE inhibition and to signs of organ damage including microalbuminuria. Tuelve men and five "lomen with essential arterial hypertension were selected for the study (mean age $27 \pm 6$ years). They persistent!y had an outpatient systolic blood pressure greater than $160 \mathrm{mmHg}$ and a diastolic blood pressure greater than $100 \mathrm{mmHg}$ on an unrestricted diet and without drug therapy, as measured on three different days after $5 \mathrm{~min}$ in the supine position. Secondary forms of hypertension were excluded by physical examination and routine laboratory investigations. Examinations concerning renal haemodynamics and organ damage were done in a blind manner by independent physicians without knowing renin values. Left ventricular wall thickness was measured by echocardiography (two-dimensional echocardiography combined with $\mathbf{M}$-mode). Hormone concentrations were determined at the end of the study period. In patients with high concentrations of renin activity a transarterial angiography was performed to exclude renal artery stenosis.

At the end of the investigation patients were assigned to two groups according to their renin concentrations after ACE inhibition. Group 1 was defined as having a false positive captopril test, according to the criteria of Muller et al. [2]. Most of these patients had elevated stimulated renin activities ( $>4 \mathrm{ng} / \mathrm{ml}$ per hour) or showed an increase $>400 \%$ of renin activities after ACE inhibition.

Patient characteristics are described in Table 1. There was no difference concerning protein or sodium intake. All patients were allowed to stay on their normal diet.

Blood pressure and microalbuminuria were measured on at least three consecutive days. A so-called white coat hypertension was ruled out by $24 \mathrm{~h}$ blood-pressure measurements (Spacelabs 90202, Spacelabs Inc., Redmond Wash). Blood pressure values given in Table 1 were also obtained by these measurements and are given as mean values. This device uses a standard upper arm cuff which is inflated at regular preset intervals (every $20 \mathrm{~min}$ ). Systolic, diastolic, and mean arterial blood pressures were calculated and interpreted by the help of an algorithm as the arterial

Table 1. Patient characteristics

\begin{tabular}{lcc}
\hline Characteristics & Group 1* & Group 2* \\
\hline Age (ycurs) & $25.7 \pm 7.3$ & $28 \pm 3.9$ \\
Body mass index (kg m${ }^{2}$ ) & $22.6 \pm 1.9$ & $26.2 \pm 4.8$ \\
Basal systolic BP (mmHg) & $172 \pm 12$ & $168 \pm 21$ \\
Basai diastolic BP (mmHg) & $99 \pm 8$ & $100 \pm 7$ \\
Mean arterial pressure (mmHg) & $123 \pm 7$ & $122 \pm 10$ \\
Basal pulse (beats min) & $75 \pm 10$ & $76 \pm 15$ \\
Duration of hypertension (months) & $23 \pm 24$ & $31 \pm 14$ \\
Creatinine (mg d!) & $0.9 \pm 0.1$ & $0.9 \pm 0.1$ \\
Sodium excretion (mval 1) & $114 \pm 16$ & $96 \pm 19$ \\
Positive family history for & & \\
hypertersion (total numbers) & 7 & 3 \\
Subjucth (n) & 9 & 8 \\
\hline
\end{tabular}

"Mean values \pm SD.

Group 1, patients with elevated plasme renir actitity after ACE intibition: ste Table 2.

Group 2. patients with normal plasma renin activity after ACE inhioition, see Table 2.

BP, blood pressire. pressure fluctuations are transmitted to the cuff and tubing system oscillometrically.

Concentrations of renin, aldosterone, and antidiuretic hormone were assessed. According to Muller et al. [2] blood for determining plasma renin actility was drawn oniy when a normal sodium excretion rate was guaranteed furinary sodium was $>80 \mathrm{mral}$ l in all patients). For routine blood intestigations and evaluation of hormone concentrations blood was ob:ained after lying supine for $30 \mathrm{~min}$. Then $\mathbf{2 5} \mathrm{mg}$ captopril were administered orally. Sixty minutes later venous blood samples were drawn for measurement of stimulated plasma renin activities. Arterial blood pressure was measured at the beginning and every $15 \mathrm{~min}$.

Sodium, potassium, chloride, creatinine, urea nitrogen, and glucose concentrations in serum samples were measured with an automated system of chemical analysis (Hitachi, Boehringer). The peripheral venous haematocrit was determined by microhaematocrit technique. Urinary albumin was measured by enzyme-linked immunosorbent assay [3]. Urine samples were collected in 2-1 casein-coated polyethylene containers. Plasma renin activity, vasopressin, and aldosterone values were determined with commercially available radioimmunoassays.

Glomerular filtration rate (GFR) and renal blood flow were assessed by means of a constant infusion technique of inulin (Inutest; Laevosan; $20 \mathrm{ml}$ contains $5.0 \mathrm{~g}$ polyfructosan) and PAH (p-aminohippurate; Nephrotest; BAG; $10 \mathrm{ml}$ contain $2.2 \mathrm{~g}$ sodium aminohippurate) after an initial loading dose starting at $8.30 \mathrm{a} . \mathrm{m}$. (loading dose for inulin: $36 \mathrm{ml} / \mathrm{m}^{2}$ body surface area; loading dose for PAH: $6 \mathrm{ml} / \mathrm{m}^{2}$ body surface area) [4]. The $C_{1 N}$ and $C_{P A H}$ were calculated as urine concentration divided by plasma concentration, multiplied by urine volume in millilitres per minute, and corrected for body surface area $\left(1.73 \mathrm{~m}^{2}\right)$. Since there were no significant differences in urine flow rates or clearances from one collection period to another, all results were expressed as single mean values of the triplicate determinations for each patient. The filtration fraction was calculated as $\mathrm{C}_{\mathrm{IN}} / \mathrm{C}_{\mathrm{PAH}}$ and was expressed as a percentage of $\mathrm{C}_{\mathrm{PAH}}$.

Student's $t$-test was used to determine statistical significance $(P<0.05)$. Linear regressions and correlation coefficients were calculated to relate albuminuria and plasma renin activities after $A C E$ inhibition.

\section{Results}

Both study groups were comparable with regard to age and arterial blood pressure measured by $24 \mathrm{~h}$ blood pressure measurement. There were no statistically significant differences regarding history of hypertension and body mass index, nor in serum concentrations of electrolytes, glucose, blood urea nitrogen, venous haematocrit, and creatinine. The difference in sodium excretion (114 \pm 16 mval 1 versus $96 \pm 19$ mval l) was not statistically significant.

There were significant $(P<0.01)$ differences in piasma renin activities after ACE inhibition (grois l, $8.4 \pm 5.3 \mathrm{ng} \mathrm{ml}$ per hour; group 2, $2.2 \pm 1.3 \mathrm{ng} \mathrm{ml} \mathrm{per}$ hour; see aiso Table 2). Baseline plasma renin activities were slightly but not significantly increased in group 1 (group 1, $2.0 \pm 1.1$; group 2, $1.5 \pm 0.3$ ). The increase in renin activity after ACE inhibition 
Table 2. Patient renin, aldosterone and vasopressin profile

\begin{tabular}{lcc}
\hline Profile & Group 1 & Group 2 \\
\hline $\begin{array}{l}\text { Baseline renin activities } \\
\text { (supine position) (ng/ml per hour) }\end{array}$ & $2.0 \pm 1.1$ & $1.5 \pm 0.3$ \\
$\begin{array}{l}\text { Renin activities after } \\
\text { oral administration of }\end{array}$ & $84 \pm 5.3$ & $2.2 \pm 1.3^{*}$ \\
$\begin{array}{l}25 \mathrm{mg} \text { captopril (ng/ml per hour) } \\
\text { Increase of renin activities } \\
\text { after ACE inhibition (\%) }\end{array}$ & $610 \pm 175$ & $190 \pm 44^{* *}$ \\
$\begin{array}{l}\text { Aldosterone }(\mathrm{pg} / \mathrm{ml}) \\
\text { Vasopressin }(\mathrm{pg} / \mathrm{ml})\end{array}$ & $\begin{array}{c}116 \pm 37 \\
6 \pm 4\end{array}$ & $\begin{array}{c}116 \pm 41 \\
3 \pm 2^{*}\end{array}$ \\
\hline
\end{tabular}

*Statistically significant.

** Mean values $\pm \mathrm{SD}$ of the respective individual increase.

expressed as mean values of the individual increase was more pronounced in group $1(610 \pm 175 \%)$ than in group $2(190 \pm 44 \%)$. Unlike plasma renin activity, there were essentially no notable differences in plasma aldosterone between the groups. Vasopressin concentrations were higher in group 1 , with elevated renin activities after ACE inhibition. This difference was not statistically significant.

As regards renal function, the differences of inulin clearance $\left(119 \pm 13 \mathrm{ml} / \mathrm{min}\right.$ per $1.73 \mathrm{~m}^{2}$ in group 1 versus $105 \pm 5 \mathrm{ml} / \mathrm{min}$ per $1.73 \mathrm{~m}^{2}$ in group 2) and filtration fraction ( $28 \pm 3 \%$ in group l versus $22 \pm 3 \%$ in group 2) were significant. PAH clearance and effective renal plasma flow (ERPF) were slightly but not significantly elevated in group 2 (Table 3 ).

Investigations concerning organ involvement (Table 4) showed that in group 1 seven of nine patients showed hypertensive fundoscopic changes ( $n=5$ for grade 1, $n=2$ for grade 2 ). In contrast, in group 2 only four of eight patients showed fundoscopic changes which were less severe than in group 1 (no grade 2). Echocardiographic diameters of the interventricular septum and posterior wall were elevated in group 1 and normal in group 2. Microalbuminuria was significantly higher in group 1 (102 $55 \mathrm{mg} / 24 \mathrm{~h}$ versus $17 \pm 7 \mathrm{mg} / 24 \mathrm{~h}$ ).

Patients with elevated plasma renin activities after ACE inhibition (group 1) had a positive correlation of albuminuria and stimulated plasma renin activities (Figure 1).

Table 3. Renal function and haemodynamics

\begin{tabular}{lcc}
\hline Parameters & Group I & Group 2 \\
\hline $\begin{array}{l}\text { Inulin clearance }\left(\mathrm{C}_{\mathrm{LV}}\right) \\
\left(\mathrm{ml} / \text { min per } 1.73 \mathrm{~m}^{2}\right)\end{array}$ & $119 \pm 13$ & $105 \pm 5^{\circ}$ \\
$\begin{array}{l}\text { p-aminohippurate } \\
\text { clearance }\left(\mathrm{C}_{\mathrm{PAH}}\right)\left(\mathrm{ml} \text { min per } 1.73 \mathrm{~m}^{2}\right)\end{array}$ & $430 \pm 83$ & $482 \pm 57$ \\
$\begin{array}{l}\text { Filtration fraction } \\
\left(\mathrm{C}_{\mathrm{IV}} \mathrm{C}_{\mathrm{PAH}} \times 100 \%\right)\end{array}$ & $28 \pm 3$ & $22 \pm 3^{\circ}$ \\
\hline
\end{tabular}

*Statistically significant.
Tabłe 4. Organ involvement and microalbuminuria

\begin{tabular}{lll}
\hline & Group 1 & Group 2 \\
\hline $\begin{array}{l}\text { Abnormal fundoscopy }(n) \\
\text { hypertensive fundus }\end{array}$ & 7 & 4 \\
$\begin{array}{l}\text { grade 1 }(n) \\
\text { hypertensive fundus } \\
\text { grade 2 }(n)\end{array}$ & 5 & 4 \\
$\begin{array}{l}\text { Diameter of } \\
\text { end-diastolic septum (mm) }\end{array}$ & 2 & 0 \\
$\begin{array}{c}\text { Diameter of posterior } \\
\text { wall, end-diastolic }(\mathrm{mm})\end{array}$ & $11.7 \pm 1.3$ & $9.4 \pm 07^{*}$ \\
Microalbuminuria (mg/24 h) & $102 \pm 57$ & $17 \pm 7^{*}$ \\
\hline
\end{tabular}

*Statıstically significant.

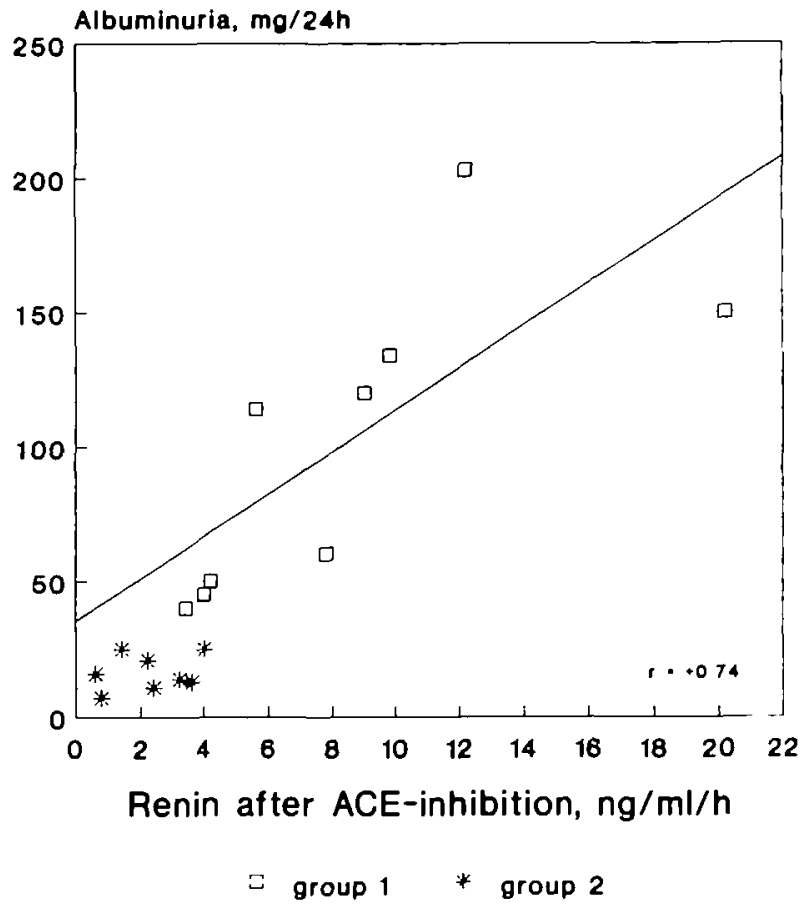

Fig. 1. Correlation of stimulated renin activities (renin after ACE inhibition) and microalbuminuria in young hypertensive patients. Group 1, patients with elevated plasma renın activity after ACE inhibition (25 mg captopril, see Table 2); Group 2, patients with normal plasma renin activity after ACE inhibition $(25 \mathrm{mg}$ captopril, see Table 2).

$r=$ correlation coefficient

\section{Discussion}

In a population of young hypertensive patients up to $40 \%$ showed an elevation of plasma renin activities after ACE inhibition [1]. We performed this prospective investigation in order to clarify whether there are differences between young hypertensive patients with elevated and normal renin activity responses after $\mathrm{ACE}$ inhibition. We chose 17 patients without previous medication, matched for blood pressure, duration of hypertension, and age, and divided them into two 
groups according to their renin response to $\mathrm{ACE}$ inhibition.

In contrast to other investigations about differences in the renin system of hypertensives [5-9], baseline renin activities of our groups were nearly equal, with a slight but not significant advantage of group 2 . The strong response to ACE inhibition in group 1 could not be explained by differences of sodium excretion, age, or aldosterone concentrations (Tables 1,2). Despite nearly identical baseline renin activities, the responses to ACE inhibition in group 1 are comparable to those in high-renin hypertensive patients described by previous investigators [6,10-13]. The slightly elevated aldosterone in group 1 seems to be related to the overall increased renin concentration. Vasopressin was higher in group 1 than in group 2 despite comparable blood pressures. The same observation was made in patients with high-renin hypertension and was thought to be related to hypovolaemia [14]. Due to normal baseline renin activities these patients could not be clearly classified as a group of high-renin hypertensives, although we cannot exclude that we may have studied patients in an early stage of this disease.

There have been several observations on the relation of renin concentrations, renal haemodynamics, microalbuminuria, organ damage, and risk of stroke and heart attack $[7,11,13,14]$. In this context our investigation concerning renal haemodynamics and organ damage in young patients is of interest.

The assessment of renal haemodynamics (Table 3 ) showed a slight but significantly higher inulin clearance in group 1 . Renal blood flow was slightly diminished compared to group 2. Group 1 showed a significantly higher filtration fraction (Table 3). The observed renal haemodynamic changes in our patients could be interpreted as a more pronounced vasoconstriction of efferent arterioles in patients of group 1 (increased renin activities). Probably patients suffering from this form of hypertension will develop nephron damage at a later state of their disease. This might occur as sequel of the high glomerular pressure in the early state of the disease, according to observations in the rat model $[15-17]$. Our observations on renal haemodynamics are in accordance with those previously published for patients with microalbuminuria [18]. Other results concerning renal haemodynamic changes in patients with essential hypertension as to their renin status are conflicting $[5,7,9,19]$. Some investigators described a reduced glomerular filtration rate, others reported a normal or slightly elevated glomerular filtration rate. Most of these differences may be explained by heterogeneities of age, medication, and duration of hypertension. As our study groups were matched, we attach importance to the observations made, especially with reference to the differences in renal haemodynamics and renin activities in young hypertensive patients.

Microalbuminuria was evident in group 1 and there was a correlation between renin values after ACE inhibition and microalbuminuria, especial.'y in patients with a markedly increased renin activity after ACE inhibition (Figure 1). We consider microalbuminuria to reflect the exposition of nephrons to renin and angiotensin II. A correlation between albuminuria and filtration fraction or glomerular filtration rate as reported by other investigators [18] could not be reproduced in our study.

In accordance with observations that microalbuminuria is related to other organ damage [20-22], we were able to demonstrate that group 1 patients more frequently showed signs of left ventricular hypertrophy and of vascular damage during fundoscopy. Although microalbuminuria seems to reflect the situation at the renal microvascular site only, our findings of a correlation between microalbuminuria and serum renin concentrations may be the link between microalbuminuria and overall vascular organ damage. This suggests a direct renin-dependent vascular damage of the whole vascular system. This would be supported by data that in larger populations patients with highrenin hypertension showed stroke and myocardial infarction more often [23].

In conclusion, patients with increased renin concentrations after $\mathrm{ACE}$ inhibition more frequently showed signs of organ damage and a more pronounced microalbuminuria. Renal haemodynamics of these patients showed increased glomerular filtration and filtration fraction. This could be interpreted as an adaptation of nephrons exposed to increased concentrations of renin and angiotensin II. Thus far it remains unclear whether increased concentrations of renin are the key to the disease or just a response to other damage. Further follow-up investigations about the vascular system, kidney morphology and clinical outcome of these patients may answer this question and will also indicate whether our patients belong to a special form of hypertension or represent an early state of so-called high-renin hypertension.

\section{References}

1. Er!ey C.M, Ris'er T. Failure of the captoprii test to identify renovascular disease in young hypertensive patients. Nept.ron. 1991; 57: 123124.

2. Muller FB, Staly JE, Case DB el al. The captopril tes: for identifying renovascular disease in hypertensive patients. Am J.Hed 1986: 80: 633-644.

3. Krämer BK. Jesce L: Ress KM, Schmülling R-M, Risier T. Enzyme-linked immunosorbent assay for urinary albumin at low concentrations. Clin Chem 1987; 33: 609-611.

4. Risler T, Hāussler M, Ress K.M. Burger KJ, Müller GA, Kramer BK. Effects of the calcium channel blocking drug isradipine on renal function. In: Puschett JB, Greenberg A, 
ed. Diuretics III: Chemistry, Pharmacology, and Clinical Applications Elsevier 1990, pp. 285-287.

5. Kolsters G, Schalekamp MADH, Birkenhäger WH, Lever AF. Renin and renal function in benign essentual hypertension: evidence for a renal abnormality. In: Berglund $G$, Hanssen $L$, Werke L, ed. Pathophysiology and Management of Arterial Hypertension. Sweden, Astra Pharmaceuticals AB 1975, pp. 54-65.

6. Case DB, Wallace JM, Keim HJ, Weber MA, Sealy JE, Laragh $\mathrm{JH}$. Possible role of renin in hypertension as suggested by renin-sodium profiling and inhibition of converting enzyme. N Engl J Med 1977; 296 641-646.

7. Pedersen EB, Kornerup HJ. Renal hemodynamics and plasma renın in patients with essential hypertension Clin $\mathrm{Scl} \mathrm{Mol}$ Med 1976; 50. 409-414.

8 Sealy JE, Blumenfeld JD, Bell GM, Pecker MS, Sommers SC, Laragh JH. On the renal basis for essential hypertension nephron heterogeneity with discordant renin secretion and sodium excretion causing a hypertensive vasoconstriction volume $J$ Hypertens 1988; 6: 763-777.

9 Reubi FC, Weidmann P, Hodler J, Cottier PT. Changes in renal function in essential hypertension. $A m J$ Med 1978; 64. 556-563

10. Case DB, Wallace JM, Keim HJ et al Estimating renın participation in hypertension. Superiority of converting enzyme inhıbition over Saralasin. Am J Med 1976: 61 · 790-79.

11. Laragh JH, Resnick LM. Recognizing and treatıng two types of long-term vasoconstriction in hypertension Kidney $/ n t 1988$ 34 [Suppl 25]: S162-S174.

12 Gavras H, Brunner HR, Laragh JH, Sealy JE, Gavras I, Vukovich RA. An angiotensin converting-enzyme inhibitor to identufy and treat vasoconstrictor and volume factors in hypertensive patients. $N$ Engl J Med 1974; 291: 817-821

13. Case DB, Atlas SA, Laragh JH, Sealy JE, Sullivan PA, McKinstry DN. Clinical experience with blockade of the renin-angiotensin-aldosterone system by an oral convertingenzyme inhibitor (SQ 14,225, Captopril) in hypertensive patients. Prog Cardiovasc Dis 1978; 31 195-206.

14 Laragh JH, Sealy JE. The renin-angotensin-aldosterone system in hypertensive disorders: A key to two forms of arteriolar vasoconstriction and a possible clue to risk of vascular injury (heart attack and stroke) and prognosis. In Laragh, Brenner, ed Hypertension, Pathophysiology', Diagnosis and Management, Vol. I, Raven Press, New York. 1990; pp. 1329-1348.

15. Brenner BM. Nephron adaptation to renal injury or ablation. Am J Physiol 1985; 249: F324-F337.

16. Olson JL, Wilson SK, Heptinstall RH Relation of glomerular injury to preglomerular resistance in experimental hypertension. Kidney Int 1986, 29. 849-856.

17. Bauer JH, Brooks CS, Burch RN. Renal function and hemodynamic studies in low-and normal-renin essential hypertension. Arch Intern Med 1982; 142: 1317-1323.

18 Losito A, Zampi I, Fortunati I, del Favero A. Glomerular hyperfiltration and albuminuria in essentual hypertension Nephron 1988; 49: 84-85.

19. Bohrer MP, Deen WM, Robertson CR et al. Mechanism of angiotensin II-induced proteinuria in the rat $A m$ J Phistol 1977; 233: F13-F21.

20. Kannel WB, Stampfer MJ, Castelh WP, Verter J. The prognostic significance of proteinuria: The Framingham study. Am Hearl J 1984; 108. 1347-1352.

21 Samuelsson $O$. Proteinura as a prognostic factor during long term hypertensive care. Drugs 1988; 35 [Suppl 5]: 48-54.

22. Schmieder R, Grube E, Rüddel H, Schlebusch $H$, Schulte $W$ Bedeutung der Mikroproteinure zur Früherkennung hypertoniebedingter Endorganschäden. Klin Wochenschr 1990, 68: 256-262.

23. Brunner HR, Laragh JH, Baer L et al. Essential hypertension: renin and aldosterone, heart attack and stroke. $N$ Engl J Med 1972; 286 : 44 I-449.

Received for publication 104.91

Accepıed in revised form 117.91 